\title{
Pemberdayaan pengelolaan desa wisata berkelanjutan di Desa Tanjung Lanjut Kecamatan Sekernan Kabupaten Muaro Jambi
}

\author{
Firmansyah Putra*, Saidina Usman, dan M. Yusuf \\ Program Studi Ilmu Pemerintahan, Fisipol, Universitas Jambi \\ * firmansyahputra@unja.ac.id
}

\begin{abstract}
Abstrak. Desa Tanjung Lanjut kecamatan Sekernan kabupaten Muaro Jambi memiliki potensi di sektor wisata indah yang berwujud berupa danau Tangkas. Danau tersebut memiliki daya tarik tersendiri dengan tumbuhnya pohon Putat berbunga Flanconia Valida berwarna merah yang mekar dan gugur sekitar bulan Juli hingga Agustus setiap tahun. Potensi objek wisata kawasan ini telah dikelola oleh Badan Usaha Milik Desa, akan tetapi belum dikelola secara berkelanjutan yang berdampak pada peningkatan pendapatan bagi masyarakat. Berdasarkan permasalahan di atas, maka rumusan solusi yang diimplemetasikan pada kegiatan pengabdian adalah pendampingan pengelolaan objek wisata dan promosi objek wisata. Pemberdayaan pengelolaan objek wisata dilakukan dengan cara: 1). Transfer pengetahuan pengelolaan berkelanjutan (mencakup aspek ekonomi, sosial dan lingkungan). 2) Pelatihan dan pendampingan peningkatan kemampuan. Berdasarkan hasil kegiatan pengabdian menunjukkan bahwa adanya peningkatan pengetahuan, motivasi, kemampuan manajerial dan kecakapan teknis dalam pengelolaan potensi wisata berkelanjutan yang berdampak pada peningkatan jumlah pengunjung. Bertambahnya jumlah wisatawan melahirkan sumber perekonomian baru atau alternatif bagi masyarakat setempat yang selama ini hanya bergantung pada sektor perkebunan dan pertanian. Temuan lain menunjukkan bahwa pengelola danau Tangkas belum memiliki kemampuan kerjasama dan jejaring yang cukup baik dengan berbagai level mitra, dengan demikian perlu dilakukan pendampingan lebih lanjut dalam peningkatan kemampuan kerjasama dan berjejaring.
\end{abstract}

Kata kunci: pemberdayaan; desa wisata; berkelanjutan

\begin{abstract}
Tanjung Lanjut Village Sekernan sub-district of Muaro Jambi region has Tangkas lake as potential of beautiful tourism. The lake has a unique attraction with the Putat tree flowering red Flanconia Valida which blooms and falls around July to August in every year. The potential of tourist attractions in this village managed by Village-Owned Enterprises but has not sustainable and has not an impact on increasing income for the local community. Based on the problems above, the solution implemented in the community service activities is the assistance of the of tourism and promotion. This empowering activity is carried out by 1). Transfer of knowledge of sustainable management (economic, social, and environmental aspects). 2) Training and capacity building assistance. Based on the results of service activities, there was an increase in knowledge, motivation, managerial ability, and technical skills in managing sustainable tourism potential, which had an impact on increasing the number of visitors. Impact the increasing of the visitors contribute new economic resources or alternatives for local people who have only relied on the plantation and agriculture sectors. Other findings indicate that the management of Tangkas Lake did not have sufficient cooperation and networking capabilities with various levels of partners. Thus further assistance is needed in enhancing collaboration and networking skills.
\end{abstract}

Keywords: empowerment; tourism village; sustainable

To cite this article: Putra, F., S. Usman, \& M. Yusuf. 2019. Pemberdayaan Pengelolaan Desa Wisata Berkelanjutan di Desa Tanjung Lanjut Kecamatan Sekernan Kabupaten Muaro Jambi. Unri Conference Series: Community Engagement 1: 83-88. https://doi.org/10.31258/unricsce.1.83-88

(C) 2019 Authors

Peer-review under responsibility of the organizing committee of Seminar Nasional Pemberdayaan Masyarakat 2019 


\section{PENDAHULUAN}

Kegiatan pendabdian ini dilaksanakan di danau Tangkas (Tanjung Kaos) desa Tanjung Lanjut yang telah dikelola sejak tahun 2017. Pengelolaan objek wisata danau Tangkas dihadapkan berbagai persoalan seperti masih sulitnya akses terhadap tujuan, pengetahuan dan pengelolaan yang lemah, hingga minimnya promosi melalui media baru. Berangkat dari berbagai masalah tersebut, masalah utama yang dihadapi adalah lemahnya tata kelola wisata berkelanjutan dan lemahnya promosi objek wisata. Masalah tersebut tercermin melalui pengelolaan objek wisata yang belum optimal untuk dijadikan sebagai sumber pendapatan bagi masyarakat sekitar. Sementara Danau Tangkas memiliki kekhasan tersendiri yang dapat dikelola secara maksimal sebagai objek wisata berkelanjutan. Selama ini masyarakat lebih fokus pada pendapatan dari sektor pertanian dan ditunjang dengan kegiatan ternak sebagai pendamping.

Masalah tersebut ditambah dengan promosi destinasi melalui penggunaan media baru yang masih lemah. Danau Tangkas yang dimiliki oleh desa belum dipromosikan secara luas yang dapat diakses dengan efektif dan efisien, sehingga danau Tangkas belum dikenal luas oleh pengunjung domestik maupun pengunjung internasional. Minimnya penyebarluasan informasi tersebut berdampak pada objek wisata yang belum dijadikan sebagai salah destinasi di provinsi Jambi. Pada umunya wisata di Jambi masih cenderung menonjolkan wisata budaya seperti situs candi, wisata alam seperti gunung dan danau. Objek wisata pada skala desa belum mendapat porsi yang setara dengan objek wisata alam dan budaya yang ada di provinsi Jambi.

Masalah tersebut dipandang sebagai permasalahan ketenagakerjaan, keterbatasan sumber mata pencaharian dan permasalan sosial ekonomi. Oleh karena itu pemberdayaan terhadap kelompok pengelola (BUMDes) wisata danau Tangkas menjadi penting, karena melalui kegiatan pemberdayaan proses transfer pengetahuan dan skill (kecakapan teknis) dapat dilakukan dengan masksimal. Pengelolaan wisata pada skala desa dapat memberikan alternatif sumber penghidupan bagi masyarakat sehingga tidak hanya tergantung pada sektor pertanian dan perikanan.

Pentingnya desa wisata berkelanjutan didasari atas argumentasi bahwa: pertama, eksistensi desa wisata mendorong kemandirian desa dalam meningkatkan pendapatan asli desa dari hasil pengelolaan kawasan wisata skala desa sebagaimana termaktub dalam UU No 6 Tahun 2014 tentang Desa (Indonesia, 2014). Kedua, eksistensi desa wisata berdampak pada terciptanya kegiatan ekonomi bagi masyarakat yang menjadi bagian dari desa wisata tersebut.

Urgensi dari desa wisata ditunjang dengan argumentasi bahwa pariwisata merupakan salah satu sektor penggerak perekonomian yang perlu mendapat perhatian di bidang pengelolaan berdasarkan konsep tata kelola yang baik (good governance). Tata kelola yang baik diperlukan untuk menjamin keberlanjutan keberadaan objek wisata baik pada skala nasional maupun pada desa. Wisata desa perlu mendapat perhatian utama untuk dikelola secara mandiri oleh pemerintah desa melalui badan usaha milik desa (BUMDes). Pengelolaan wisata menjadi menarik dan penting dilakukan karena menawarkan objek yang berbasis kearifan lokal dengan kekhasan di masing-masing desa (Zakaria \& Suprihardjo, 2014).

Pembangunan di sektor wisata perlu dilakukan dengan konsep berkelanjutan (sustainable), dimana pengelolaanya mempertimbangkan dampak ekologis, ekonomi dan sosial terhadap masyarakat. Upaya pembangunan seperti ini diatur agar mampu meningkatkan kualitas hidup masyarakat dengan cara pengaturan, penyediaan, pengembangan, pemanfaatan dan pemeliharaan objek wisata secara konsisten untuk menjaga dan mempertahankan masa depan bangsa. Dengan pola demikian diharapkan akan tercipta sumber perekonomian bagi masyarakat desa dan berkontribusi terhadap pendapatan asli desa (Haryanto, 2013).

Desa wisata merupakan salah satu bentuk nyata pariwisata yang menawarkan objek wisata di dalam atau dekat dengan kehidupan masyarakat yang tinggal di desa. Kegiatan desa wisata mengintegrasikan atraksi, akomodasi dan fasilitas pendukung dengan struktur kehidupan masyarakat di daerah tertentu (Dewi, Fandeli, \& Baiquni, 2013). Desa wisata memiliki nilai yang tinggi karena kekhasan kegiatan yang terintegrasi antara objek wisata dengan dinamika kehidupan sosial masyarakat yang di setiap daerah yan g beragam.

Pengembangan dan pengelolaan desa wisata sesuai dengan undang-undang desa yang memberikan kewenangan besar untuk mengelola sumber daya yang ada di desa (Indonesia, 2014). Namun demikian pada perkembangannya pengelolaan wisata di tingkat desa yang tergolong masih baru dihadapkan berbagai persoalan baik pada pendanaan, akses, akomodasi hingga tata kelola. Hal ini terjadi karena tidak semua desa memiliki kapasitas sumber daya manusia yang mumpuni untuk mengelola potensi desa dengan baik.

Persoalan yang sama dihadapi oleh masyarakat desa Tanjung Lanjut, selama ini kecendrungan bertumpu pada kegiatan pertanian dan perkebunan (sawit). Ketergantungan terhadap komoditas tersebut tidak disertai dengan penguasaan teknologi yang mutakhir dan pengetahuan untuk meningkatkan produktifitas. Pada konteks 
globalisasi muncul persoalan yang menimpa petani kelapa sawit, munculnya kampanye "sawit kotor" berimplikasi secara langsung terhadap harga jual CPO milik petani.

\section{METODE PENERAPAN}

Kegiatan pengabdian kepada masyarakat ini dilakukan dengan menggunakan pendekatan participatory learning and action (PLA). Istilah lain PLA pada kegiatan pemberdayaan masyarakat yang juga dikenal dengan konsep learning by doing atau belajar sambil bekerja (Ibnouf, Sheqwarah, \& Sultan, 2015). Melalui metode PLA, pengabdian dilakukan melalui proses belajar melalui ceramah atau tutorial, curah pendapat dan diskusi. Pembekalan kepada masyarakat akan diberikan kesadaran tentang pentingnya pencarian sumber ekonomi alternatif selain sumber pertanian yang saat ini mayoritas dilakukan oleh masyarakat desa. Adapun proses pendapingan dilakukan melalui tahapan berikut:

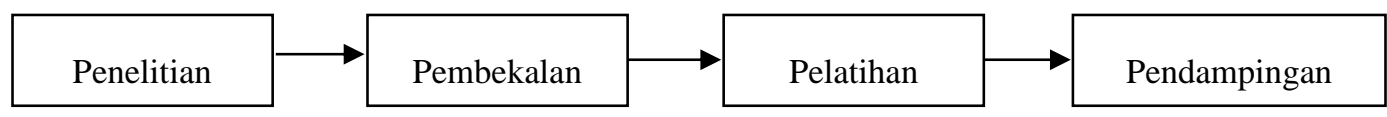

Kegiatan pemberdayaan diawali dengan penelitian awal yang bertujuan untuk mengidentifikasi masalah yang terjadi pada objek pengabdian. Kemudian temuan-temuan tersebut ditindak lanjuti dengan penelitian lanjutan sebelum pelaksanaan kegiatan pengabdian. Pada proses inilah tim pendamping juga melakukan pendekatan secara intensif baik melalui personal maupun secara kelembagaan kepada mitra (pengelola BUMDes) dengan harapan proses pelaksanaan akan mudah direalisasikan. Penelitian awal dan lanjutan sangat penting dilakukan karena, melalui kedua proses tersebut kegiatan pendampingan dapat menemukan problem utama yang dihadapi oleh mitra dan menemukan rumusan penyelesaian masalah yang relevan dengan problematika di lapangan.

\section{Pembekalan}

Pembekalan dilakukan untuk mentransfer pengetahuan mengenai: pentingnya keberadaan desa wisata, potensi objek daya tarik wisata (OTDW) yang dapat digali dan dikelola pada skala desa, serta dampak keberadaan desa wisata bagi perekonomian masyarakat dan ketenagakerjaan. Pada proses pembekalan ini juga dilakukan curah pendapat, diskusi, saling berbagi pengalaman, memberikan contoh pariwisata yang telah maju sehingga meningkatkan motivasi masyarakat/kelompok untuk melaksanakan kegiatan pembantukan desa wisata.

\section{Pelatihan}

Pelatihan yang dilakukan untuk menciptakan hubungan-hubungan kelakuan yang efektif antar anggota, sehingga dapat bekerja sama secara efisien dan efektif guna mencapai tujuan atau sasaran tertentu. Pelatihan dilakukan untuk memberikan kemampuan pemetaan potensi objek daya tarik wisata, pengambilan gambar, pengelolaan dan penulisan konten media sosial sebagai wadah promosi.

\section{Pendampingan}

Pendampingan dilakukan bertujuan untuk mengasah keterampilan dalam mengelola wisata sehingga, kelompok sasaran memiliki wawasan dan kecakapan teknis pengelolaan desa wisata. Langkah ini dilakukan untuk mendampingi seluruh kegiatan untuk peningkatan pengelolaan desa wisata.

Kegiatan pengabdian melalui proses penelitian, pembekalan, pelatihan dan pendampingan ini dilakukan secara berkelanjutan untuk menemukan berbagai tantangan yang dihadapi kemudian menemukan peluang yang dapat dicapai oleh mitra. Oleh karena itu kegiatan ini akan memberikan rekomendasi kegiatan lanjutan yang perlu mendapat perhatian khusus terhadap persoalan yang di hadapi oleh desa tanjung lanjut dalam mengelola desa wisata.

\section{HASIL DAN KETERCAPAIAN SASARAN}

Danau Tangkas terletak di dua desa yaitu desa Tanjung Lanjut kecamatan Sekernan kabupaten Muaro Jambi dan desa Kaos kecamatan Pemayung kabupaten Batanghari. Penamaan danau Tangkas diambil dari nama desa Tanjung Lanjut dan Kaos karena letaknya berada di kedua wilayah administratif desa tersebut. Danau seluas \pm 40 ha ini memiliki daya tarik melalui objek wisata danau rawa yang masih alami, selain itu daya tarik khusus danau ini terletak pada bunga Flanconia Valida dari pohon Putat yang gugur sekitar bulan Juli setiap tahun. Dari segi aksesibilitas danau ini berjarak hanya sekitar 40 kilometer dari kota Jambi sehingga masih mudah 
dijangkau melalui desa Tanjung Lanjut. Kunjungan objek wisata hanya dapat dilakukan melalui desa Tanjung Lanjut karena, pengelolaannya saat ini hanya dilakukan oleh pemerintah desa Tanjung Lanjut melalui BUMDes, sementara di kawasan desa Kaos belum dikelola.

Melalui kegiatan pengabdian kepada masyarakat danau ini dijadikan sebagai objek pengabdian karena beberapa permasalahan sebagaimana diuraikan di atas. Kegiatan pengabdian dilakukan selama 4 bulan (MaretJuni tahun 2019). Kegiatan ini dilakukan atas dasar argumentasi bahwa persoalan yang muncul dalam pengelolaan desa wisata salah satunya adalah belum optimalnya kualitas sumber daya manusia (Priyanto \& Safitri, 2016). Paradigma developmentalisme yang menggunakan pendekatan top-down dianggap gagal dalam memahami dinamika kebutuhan masyarakat, maka pendekatan buttom-up yang bertumpu pada masyarakat (community-based development) menuju pembangunan yang diarahkan oleh masyarakat (community-driven development) harus didorong untuk menemukan isu strategis dalam pembangunan (Sulistiyani \& Wulandari, 2017; Widayanti, 2012).

Pelaksanaan kegiatan pengabdian diawali dengan riset pendahuluan untuk mengidentifikasi pokok permasalahan dan potensi desa yang dapat dikembangkan melalui kegiatan pengabdian. Pada proses riset ditemukan permasalahan utama yang dihadapi oleh masyarakat desa, persoalan tersebut pada dasarnya terletak pada ketergantungan masyarakat desa pada sektor perkebunan (Sawit). Di satu sisi perkebunan sawit telah berkontribusi terhadap perekonomian masyarakat, akan tetapi di sisi lain ketergantungan memiliki implikasi yang kompleks karena dihadapkan pada situasi global (isu sosial dan lingkungan) yang mempengaruhi nilai jual crude palm oil $(\mathrm{CPO})$ kepada perusahaan pembeli. Ekstrimnya harga $\mathrm{CPO}$ petani dari tengkulak bahkan hanya Rp. 300 perkoligram ditambah lagi dengan monopoli harga oleh perusahaan yang menjadikan harga tidak dapat bersaing.

Selain harga yang rendah akibat isu sosial dan lingkungan, persoalan teknis juga dihadapi oleh masyarakat desa. Masalah tersebut berkaitan dengan bibit yang tidak bagus, teknologi yang tidak mumpuni dan pengetahuan yang kurang tentang pertanian sawit pada umumnya. Lebih luas lagi, permasalahan menjadi berantai karena mulai dari penguasaan lahan yang rawan konflik, penanaman dan pemeliharaan membutuhkan biaya yang tinggi, hasil panen yang fluktuatif hingga pemasaran yang dimonopoli oleh perusahaan. Jika perekonomian hanya bergantung pada sektor sawit tentu rantai tersebut tidak akan terputus karena petani skala kecil bergantung pada hilirisasi hasil panen.

Kajian lanjut dilakukan dengan memetakan potensi desa Tanjung Lanjut, berbagai potensi yang ada di desa ini pada dasarnya dapat dikelola untuk kemandirian desa yang berdampak pada perekonomian masyarakat desa. Berdasarkan hasil penelitian, maka langkah selanjutnya adalah menentukan satu tema khusus yang akan dijadikan sebagai objek pengabdian. Desa Tanjung Lanjut memiliki danau yang menjadikan khas, sementara desa lain tidak memiliki danau yang indah maka pendampingan difokuskan pada kegiatan pengelolaan potensi wisata desa. Atas dasar kekhasan tersebut maka tim kegiatan pengabdian membangun kerjasama dengan pemerintah desa dan BUMdes desa Tanjung Lanjut untuk melakukan kegiatan pengelolaan potensi wisata desa dan promosi objek wisata.

Danau tangkas pada dasarnya sudah mulai dikelola secara intensif sejak tahun 2017 oleh pemerintah desa, akan tetapi pengelolaanya mulai efektif sejak awal tahun 2018. Pengelolaan diawali pembersihan di wilayah pinggiran danau kemudian dilanjutkan dengan pembangunan dermaga dan pondokan rakit. Danau ini kemudian diresmikan oleh bupati Muaro Jambi pada bulan Agustus tahun 2018. Setelah diresmikan objek wisata ini belum mendapat respon baik oleh masyarakat luas, persoalan utamanya terletak pada kurangnya promosi melalui berbagai saluran komunikasi baru. Selain belum terekspos secara luas, permasalahan mendasar terkait pengelolaan yang belum tergornaisasi dengan baik.

Berangkat dari fakta lemahnya tata kelola dan minimnya penyebarluasan informasi maka kegiatan difokuskan untuk menyelesaikan kedua persoalan tersebut. Pada kegiatan ini menawarkan solusi pengelolaan objek wisata melalui pendampingan dalam penggalian kembali objek-objek wisata yang belum terdeteksi, pencatatan dan dokumentasi objek wisata, serta pembuatan penanda lokasi wisata (peta, petunjuk arah dan lainnya). Penyebarluasan informasi dilakukan melalui pendampingan promosi objek wisata menggunakan saluran komunikasi media baru (online), saluran ini digunakan untuk menyesuaikan terhadap dampak determinasi perkembangan teknologi komunikasi, selain itu saluran ini juga digunakan dengan pertimbangan efektifitas dan efisiensi mobilitas jangkauan promosi. Promosi dilakukan dengan memanfaatkan media sosial resmi (Instagram dan facebook) yang memuat konten broadcast informatif dalam bentuk template desain grafis yang menarik dengan dukungan audio visual dan video grafis.

Pemberdayaan yang diterapkan untuk menumbuhkan kekuasaan dan wewenang yang lebih besar terhadap masyarakat (pengelola desa wisata). Upaya ini dilakukan dengan menciptakan masyarakat yang memiliki 
pengaruh, mampu mengelola sumber daya yang ada, adanya partisipasi yang kuat dari masyarakat itu sendiri. Tujuan utamanya untuk membantu masyarakat memperoleh daya untuk mengambil keputusan dan menentukan tindakan yang akan ia lakukan, yang terkait dengan diri mereka, termasuk mengurangi efek hambatan pribadi dan sosial dalam melakukan tindakan (Andreas \& Savitri, 2016).

Sejalan dengan paradigma di atas, kegiatan ini juga menggunakan pendekatan buttom up yang sejalan dengan pembangunan yang sedang dilakukan oleh Indonesia yang dimulai dari pinggiran dengan memperkuat desa melalui pendanaan dana desa. Dengan demikian desa memiliki kesempatan yang besar untuk merencanakan pembangunan yang bertujuan kesejahteraan masyarakat melalui wisata berkelanjutan. Pendekatan ini juga dimaksudkan untuk menjawab kebutuhan wisatawan dimana kondisinya sarana dan prasarana kawasan destinasi belum memiliki perencanaan yang berkelanjutan. Lebih lanjut, penggalian potensi pada skala desa bertujuan untuk menfasilitasi desa dan meningkatkan kesejahteraan melalui wisata.

Selama bulan maret hingga Juni kegiatan pengabdian dilakukan dengan menekankan pada aspek pertama: penyediaan akses yang lebih terbuka, luas dan lebar terhadap sumber-sumber daya seperti modal, informasi, kesempatan berusaha dan memperoleh kemudahan/fasilitas. Aktifitas di dalamnya berupa pemberian kesempatan untuk membuka jasa layanan di bidang wisata. Kedua, pengembangan potensi SDM maupun kelembagaan masyarakat. Kegiatan yang dilakukan adalah dengan pelatihan, pendampingan dan demonstrasi, dan ketiga penyertaan masyarakat dalam proses perumusan perencanaan dan implementasi kebijakan. Cara ini menggunakan paradigma people-based and people-oriented development yang dilakukan melalui curah pendapat, berdiskusi, musyawarah dan menentukan kebijakan pengelolaan desa wisata (Andreas \& Savitri, 2016).

Pasca pelaksanaan kegiatan pengabdian dilakukan evaluasi terhadap seluruh proses penyelenggaraan untuk memperoleh informasi mengenai tingkat capaian program yang telah direncanakan. Hasil evaluasi kegiatan menunjukkan bahwa adanya peningkatan pengetahuan tentang pengelolaan wisata desa berkelanjutan yang mencakup aspek sosial, ekonomi dan lingkungan. Pengetahuan tersebut disertai dengan peningkatan motivasi kelompok sasaran kegiatan pemberdayaan, motivasi ini ditunjukkan melalui adanya keterlibatan aktif masyarakat seperti penyediaan permainan tradisional, paket perahu wisata dan pembukaan kuliner tradisional sebagai bagian yang terintegrasi dengan danau Tangkas.

Kemampuan manajerial dan kecakapan teknis dalam pengelolaan potensi wisata berkelanjutan juga mengalami peningkatan yang ditunjukkan dengan aktifitas promosi melalui saluran komunikasi baru. Promosi objek wisata melalui media baru yang popular mulai intensif disertai dengan konten-konten yang informatif, akan tetapi penggunaan wadah baru ini perlu mendapat perhatian lebih karena konten-konten yang disajikan masih kurang menarik. Begitupula dengan ketersebaran informasi, informasi belum tersebar secara massif melalui jejaring saluran komunikasi dengan pengguna media yang sudah popular.

Aktifitas pendampingan pengelolaan dan promosi objek wisata berdampak pada peningkatan jumlah pengunjung, terutama pada akhir pekan. Persoalan yang dihadapi adalah sejak danau diresmikan oleh bupati Muaro Jambi pencatatan jumlah pengunjung belum dilakukan, perekaman jumlah pengunjung baru mulai dilakukan pada akhir kegiatan pendampingan. Sehingga untuk melihat fluktuasi kunjungan tidak dapat dimunculkan setiap bulan dalam setahun.

Bertambahnya jumlah wisatawan dirasa memberi pengaruh terhadap usaha-usaha masyarakat yang menjadi bagian dari aktifitas wisata danau tangkas. Pada akhir pekan, masyarakat desa melakukan aktifitas baru seperti penjualan permainan untuk anak-anak, jalur motor track, area camping di pulai dan atraksi lainnya yang masih tahap pembangunan. Dengan adanya aktifitas baru maka melahirkan sumber perekonomian baru atau alternatif bagi masyarakat setempat yang selama ini hanya bergantung pada sektor perkebunan dan pertanian.

\section{KESIMPULAN}

Kegitan pengabdian melalui tahapan penelitain, transfer pengetahuan, pelatihan dan pendampingan berdampak pada meningkatnya pengetahuan dan kemampuan pengelolaan potensi wisata yang dapat dikembangkan sebagai aset. Pengelolaan objek wisata mulai mengarah pada penggunaan konsep berkelanjutan yang memperhatikan aspek sosial ekonomi dan lingkungan. Dari aspek ekonomi berdampak pada terbentuknya potensi sumber pendapatan baru bagi masyarakat sekitar. Hal ini terlihat dengan adanya usaha baru seperti jasa perahu, warung terapung dan paket permainan yang mulai dijadikan sebagai sumber perekonomian masyarakat dan berkontribusi bagi pendapatan asli desa.

Dari sisi lingkungan dan sosial, dijadikannya danau tangkas sebagai area wisata berimplikasi pada terjaganya wilayah tersebut dari upaya pengrusakan sehingga kehidupan sosial masyarakat terhindar dari 
persoalan seperti konflik. Dengan demikian, pengelolaan potensi wisata sebagai sumber pendapatan baru bagi masyarakat merupakan salah satu cara mengatasi persoalan ekonomi masyarakat akibat situasi global. Artikel ini berargumen bahwa metode pendampingan yang perlu dikembangkan dalam pengelolaan wisata pada tingkat desa harus dilakukan riset pendahuluan dan riset setiap tahapan. Melalui kegiatan riset diyakini mampu mendeteksi persoalan yang krusial dan membutuhkan penyelesaian dengan metode pembekalan, pelatihan dan pendampingan. Pembekalan sangat penting dilakukan karena melalui proses pembekalan akan memberikan kesadaran urgensi keberadaan desa wisata, adanya pengetahuan dan wawasan pengelolaan desa yang berkelanjutan serta terbentukanya kemampuan mengelola wisata secara mandiri pada skala desa.

Pengelolaan wisata pada desa membutuhkan kemampuan kerjasama dan jejaring yang baik untuk menunjang keberlanjutan objek wisata. Oleh karena itu, kegiatan pendampingan masyarakat selain transfer pengetahuan, pelatihan dan pendampingan, pendampingan lebih lanjut dalam membangun jejaring dan menjalin dengan berbagai stakeholder menjadi penting dilakukan.

\section{UCAPAN TERIMA KASIH}

Penulis mengucapkan terima kasih kepada Lembaga Penelitian dan Pengabdian Universitas Jambi atas dukungan pendanaan dan saran konstruktif terhadap penyelengaaraan kegiatan pengabdian kepada masyarakat, kepada Kepala Desa dan Ditektur BUMDes Desa Tanjung Lanjut yang telah bersedian menjadi mitra dan menfasilitasi kegiatan sehingga kegiatan terlaksana sesuai dengan perencanaan.

\section{DAFTAR PUSTAKA}

Andreas, \& E. Savitri. 2016. Peran Pemberdayaan Ekonomi Masyarakat Pesisir dan Modal Sosial dalam Meningkatkan Kesejahteraan di Kabupaten Meranti dan Rokan Hilir.

Dewi, M. H. U., C. Fandeli, \& M. Baiquni. 2013. Pengembangan Desa Wisata Berbasis Partisipasi Masyarakat Lokal Di Desa Wisata Jatiluwih Tabanan, Bali. Kawistara 3(2): 129-139.

Haryanto, J. T. 2013. Implementasi Nilai-Nilai Budaya, Sosial, dan Lingkungan Pengembangan Desa Wisata Di Provinsi Yogyakarta. Kawistara 3(1): 1-11.

Ibnouf, M. H., M. N. Sheqwarah, \& K. I. Sultan. 2015. An Evaluation of the Participatory Learning and Action (PLA) Training Workshop. Journal of Agricultural Science 7(12): 144-150. https://doi.org/10.5539/jas.v7n12p144

Indonesia, R. Undang-Undang Republik Indonesia Nomor 6 Tahun 2014 Tentang Desa (2014). Indonesia. https://doi.org/10.1017/CBO9781107415324.004

Priyanto, \& D. Safitri. 2016. Pengembangan Potensi Desa Wisata Berbasis Budaya: Tinjauan Terhadap Desa Wisata Di Jawa Tengah. Jurnal Vokasi Indonesia: Journal of Vocational Program Univesity of Indonesia 4(1), 2016.

Sulistiyani, A. T., \& Y. Wulandari. 2017. Proses Pemberdayaan Masyarakat Desa Sitimulyo, Kecamatan Piyungan, Kabupaten Bantul dalam Pembentukan Kelompok Pengelola Sampah Mandiri. Indonesia Journal If Community Engagement 2(2): 146-162.

Widayanti, S. 2012. Pemberdayaan Masyarakat: Pendekatan Teoritis. Welfare, Jurnal Ilmu Kesejahteraan Sosial 1(1): $87-102$.

Zakaria, F., \& R. D. Suprihardjo. 2014. Konsep Pengembangan Kawasan Desa Wisata di Desa Bandungan Kecamatan Pakong Kabupaten Pamekasan. Jurnal Teknik Pomits 3(2): 245-249. 